\title{
Strenuous exercise, plasma fibrinogen, and factor VII activity
}

\author{
J B Connelly, J A Cooper, T W Meade
}

\begin{abstract}
Objective-To assess the effect of physical activity on plasma fibrinogen and factor VII activity and thus on the risk of ischaemic heart disease.

Design-Cross sectional survey.

Setting-Ten group practices in the Medical Research Council's General Practice Research Framework.

Patients-3967 men aged 45-69 attending screening clinics for the thrombosis prevention trial.
\end{abstract}

Methods-Structured interview to elicit the intensity and frequency of physical exercise during past month. Measurement of fibrinogen, factor VII activity, cholesterol concentration, blood pressure, and other indices of ischaemic heart disease risk.

Results-Strenuous exercise was associated with significantly lower fibrinogen concentrations than mild exercise, implying a difference of about $15 \%$ in the risk of ischaemic heart disease. Strenuous exercise was also associated with lower cholesterol concentrations. More frequent strenuous exercise was associated with lower factor VII activity.

Conclusions-With the recognition of plasma fibrinogen as a strong index of ischaemic heart disease risk the results of this and other studies suggest a pathway through which the protective effect of strenuous exercise may partly be mediated and they provide doctors and patients with a valuable incentive towards prevention, particularly in those whose risk of ischaemic heart disease is substantially due to raised fibrinogen concentrations.

Plasma fibrinogen concentration is strongly and independently associated with the incidence not only of ischaemic heart disease but also of stroke. ${ }^{1-3}$ Whatever the origin of high concentrations-that is, genetic, environmental, or in response to tissue damage-there are several pathways through which they may influence thrombogenesis. These include a contribution to atherogenesis itself, to red cell and plasma viscosity, to platelet aggregability, and to the amount of fibrin deposited. ${ }^{4-8}$ Factor VII activity is also associated with the onset of ischaemic heart disease. ${ }^{12}$ Whether high concentrations of clotting factor are of causal significance can also be studied through the effects of known determinants of ischaemic heart disease on their concentrations, a clear example being that of smoking and fibrinogen. ${ }^{2910}$ The protective relation between physical activity at work ${ }^{11}$ or in leisure ${ }^{12}$ and the incidence of ischaemic heart disease is also well known. Because this exercise has to be current and continuing to confer protection against ischaemic heart disease ${ }^{12}$ there is growing reason to believe that vigorous exercise modifies the acute thrombotic component. Pathological findings also suggest that the protective effect of exercise against ischaemic heart disease is mediated through a thrombogenic rather than atherogenic pathway. Thus in the National Necropsy Survey, Morris and Crawford showed that there was no difference in the extent of coronary artery atheroma between those previously in occupations involving light, medium, or heavy physical activity. ${ }^{13}$ However, the prevalence of lumen occlusion and, in particular, of large healed infarcts was highest in those whose previous occupations had involved light physical activity, intermediate in those involving medium activity, and lowest in those involving heavy physical activity. The conclusion that exercise exerts its effect on ischaemic heart disease acutely and the practical, preventive implications would be further strengthened by the demonstration that it influences probable thrombogenic mechanisms. We therefore investigated the relation between physical exercise during leisure and plasma fibrinogen concentration and factor VII activity.

\section{Patients and methods}

Participants came from ten general practices taking part in an additional study during the screening stage for the thrombosis prevention trial (TPT). ${ }^{14}$ The purpose of the TPT is to evaluate the effects of low dose aspirin $(75 \mathrm{mg}$ ) and low intensity oral anticoagulation (International Normalised Ratio (INR) 1.5) in the primary prevention of ischaemic heart disease in high risk men aged between 45 and 69 . The first stage consists of a search of practice notes to exclude those who have previously experienced myocardial infarction or a stroke and those in whom antithrombotic threatment is contraindicated (for example, peptic ulceration, requirement for incompatible drugs). Eligible men are then invited for a screening examination, at which the risk of ischaemic heart disease is assessed on the basis of family and smoking history, body mass index (BMI), blood pressure, blood cholesterol, plasma 
Table 1 Relations between personal characteristics and intensity of exercise: numbers (and \%) in different categories

\begin{tabular}{|c|c|c|c|c|c|c|}
\hline \multirow[b]{3}{*}{$\begin{array}{l}\text { Age group (yr): } \\
\quad<50 \\
50-60 \\
>60\end{array}$} & \multicolumn{6}{|c|}{ Exercise intensity } \\
\hline & \multicolumn{2}{|c|}{$\begin{array}{l}\text { Strenuous } \\
(801(20 \cdot 2 \%))\end{array}$} & \multicolumn{2}{|c|}{$\begin{array}{l}\text { Mild } \\
(2904(73 \cdot 2 \%))\end{array}$} & \multicolumn{2}{|c|}{$\begin{array}{l}\text { None } \\
(262(6.6 \%))\end{array}$} \\
\hline & $\begin{array}{l}287 \\
335 \\
179\end{array}$ & $\begin{array}{l}(35 \cdot 8) \\
(41 \cdot 8) \\
(22 \cdot 4)\end{array}$ & $\begin{array}{r}595 \\
1234 \\
1075\end{array}$ & $\begin{array}{l}(20 \cdot 5) \\
(42 \cdot 5) \\
(37 \cdot 0)\end{array}$ & $\begin{array}{r}65 \\
135 \\
62\end{array}$ & $\begin{array}{l}(24 \cdot 8) \\
(51 \cdot 5) \\
(23 \cdot 7)\end{array}$ \\
\hline $\begin{array}{l}\text { Smoking: } \\
\text { Never } \\
\text { Ex } \\
\text { Current }\end{array}$ & $\begin{array}{l}304 \\
175 \\
322\end{array}$ & $\begin{array}{l}(38 \cdot 0) \\
(21 \cdot 8) \\
(40 \cdot 2)\end{array}$ & $\begin{array}{r}723 \\
930 \\
1238\end{array}$ & $\begin{array}{l}(25 \cdot 0) \\
(32 \cdot 1) \\
(42 \cdot 8)\end{array}$ & $\begin{array}{r}58 \\
109 \\
95\end{array}$ & $\begin{array}{l}(22 \cdot 1) \\
(41 \cdot 6) \\
(36 \cdot 2)\end{array}$ \\
\hline $\begin{array}{l}\text { Alcohol: } \\
\text { Yes } \\
\text { No }\end{array}$ & $\begin{array}{r}743 \\
55\end{array}$ & $\begin{array}{r}(93 \cdot 1) \\
(6 \cdot 9)\end{array}$ & $\begin{array}{r}2617 \\
283\end{array}$ & $\begin{array}{r}(90 \cdot 2) \\
(9 \cdot 8)\end{array}$ & $\begin{array}{r}228 \\
33\end{array}$ & $\begin{array}{l}(87 \cdot 4) \\
(12 \cdot 6)\end{array}$ \\
\hline $\begin{array}{l}\text { Body mass index } \\
<27 \\
>27\end{array}$ & $\begin{array}{l}520 \\
281\end{array}$ & $\begin{array}{l}(64 \cdot 9) \\
(35 \cdot 1)\end{array}$ & $\begin{array}{l}1783 \\
1121\end{array}$ & $\begin{array}{l}(61 \cdot 4) \\
(38 \cdot 6)\end{array}$ & $\begin{array}{l}133 \\
129\end{array}$ & $\begin{array}{l}(50 \cdot 8) \\
(49 \cdot 2)\end{array}$ \\
\hline $\begin{array}{l}\text { Occupation: } \\
\text { Non-manual } \\
\text { Manual }\end{array}$ & $\begin{array}{l}473 \\
306\end{array}$ & $\begin{array}{l}(60 \cdot 7) \\
(39 \cdot 3)\end{array}$ & $\begin{array}{l}1277 \\
1555\end{array}$ & $\begin{array}{l}(45 \cdot 1) \\
(54 \cdot 9)\end{array}$ & $\begin{array}{r}89 \\
168\end{array}$ & $\begin{array}{l}(34 \cdot 6) \\
(65 \cdot 4)\end{array}$ \\
\hline
\end{tabular}

Differences between proportions reporting varying intensity by age, smoking habit, and class ( $p$ $<0.0001)$; by BMI ( $\mathrm{p}=0.0002)$; by alcohol consumption $(\mathrm{p}=0.01)$

Numbers approximately same in table 2 (a few missing values for variables other than age, exercise, and fibrinogen). they had undertaken it during the last month. Men were classified as (a) those who had taken strenuous exercise (and mild exercise), (b) those who had taken mild but not strenuous exercise, and $(c)$ those who said they took no exercise.

Current smokers include 400 cigar or pipe smokers whose mean fibrinogen concentration was $2.83 \mathrm{~g} / 1$ compared with $2.99 \mathrm{~g} / 1$ in current cigarette smokers. Questions on alcohol consumption divided participants into those who were wholly or virtually teetotal and those who took alcohol occasionally or regularly. Social class is summarised as non-manual (I, II, and III non-manual) or manual (III manual, IV, V) occupation. The body mass index (BMI) is defined as weight $/$ height $^{2}$.

$\chi^{2}$ tests were used to assess the relation between personal characteristics and type of exercise (table 1). Analysis of covariance was used to test the relations between exercise and fibrinogen, $\mathrm{VII}_{c}$, blood pressure, and cholesterol (tables 2, and 3 and 4).

fibrinogen concentration, and factor VII activity $\left(\mathrm{VII}_{\mathrm{c}}\right)$. The main purpose of the additional study (identification of risk study) was to assess the psychological and behavioural effects of being identified as high risk for a major episode of ischaemic heart disease. During a structured interview the trial nurse also administered questions about exercise. These were similar to those in previously validated methods for distinguishing between active and inactive groups. ${ }^{16}$ Mild exercise was defined as a positive response to the question "in the last month have you taken any light activity for the purpose of exercise?" using prompt questions which gave going for a walk, playing golf, or gardening as examples. Strenuous exercise was defined as a positive response to the question "during the past month have you taken part in regular physical exercise that involves a lot of energy output?", with the prompt examples including playing soccer or rugby, jogging, fast swimming, and cycling. Those recording this type of exercise were asked how many times

\section{Results}

Of the 6187 men invited to the ten screening clinics, $4640(75 \%)$ attended. Of these, 4590 $(99 \%)$ gave information about lifestyle. A total of 245 men were excluded as ineligible for TPT: 89 because of a definite or possible past history of ischaemic heart disease or other arterial disease (including, for the purposes of this study, angina pectoris and intermittent claudication), 53 because they were on drugs incompatible with TPT treatment, and the rest for other reasons. Of the remaining 4345, 3967 $(91 \%)$ had complete information on age, exercise, and clotting factors. Table 1 shows that a small proportion $(262,6 \cdot 6 \%)$ did not report even mild exercise. A total of $801(20 \cdot 2 \%)$ men reported strenuous exercise during the past month (and nearly all these men also reported mild exercise) and the remaining $2904(73 \cdot 2 \%)$ reported mild exercise only. Compared with the other two groups, those reporting strenuous exercise were younger, were less likely to

Table 2 Mean (SD) fibrinogen concentrations $(g / l)$ according to intensity of exercise

\begin{tabular}{|c|c|c|c|c|c|c|c|}
\hline \multirow[b]{3}{*}{$\begin{array}{l}\text { Age group (yr): } \\
<50 \\
50-60 \\
>60\end{array}$} & \multicolumn{7}{|c|}{ Exercise intensity } \\
\hline & Strenuous & \multicolumn{2}{|l|}{ Mild } & \multicolumn{2}{|l|}{ None } & \multicolumn{2}{|l|}{ All } \\
\hline & $\begin{array}{ll}2.58 & (0.55) \\
2.63 & (0.52) \\
2.80 & (0.58)\end{array}$ & $\begin{array}{l}2 \cdot 63 \\
2 \cdot 77 \\
2 \cdot 88\end{array}$ & $\begin{array}{l}(0.51) \\
(0.57) \\
(0.56)\end{array}$ & $\begin{array}{l}2 \cdot 61 \\
2 \cdot 79 \\
2 \cdot 99\end{array}$ & $\begin{array}{l}(0 \cdot 48) \\
(0.58) \\
(0.57)\end{array}$ & $\begin{array}{l}2 \cdot 61 \\
2 \cdot 74 \\
2 \cdot 87\end{array}$ & $\begin{array}{l}(0.52) \\
(0.57) \\
(0.57)\end{array}$ \\
\hline $\begin{array}{l}\text { Smoking: } \\
\text { Never } \\
\text { Ex } \\
\text { Current }\end{array}$ & $\begin{array}{ll}2.55 & (0.52) \\
2.65 & (0.50) \\
2.83 & (0.61)\end{array}$ & $\begin{array}{l}2.66 \\
2.73 \\
2.96\end{array}$ & $\begin{array}{l}(0.52) \\
(0.56) \\
(0.55)\end{array}$ & $\begin{array}{l}2.65 \\
2.69 \\
2.96\end{array}$ & $\begin{array}{l}(0.49) \\
(0.55) \\
(0.60)\end{array}$ & $\begin{array}{l}2 \cdot 63 \\
2 \cdot 71 \\
2 \cdot 94\end{array}$ & $\begin{array}{l}(0.52) \\
(0.55) \\
(0.57)\end{array}$ \\
\hline $\begin{array}{l}\text { Alcohol: } \\
\text { Yes } \\
\text { No }\end{array}$ & $\begin{array}{ll}2.64 & (0.54) \\
2.75 & (0.58)\end{array}$ & $\begin{array}{l}2 \cdot 77 \\
2 \cdot 89\end{array}$ & $\begin{array}{l}(0 \cdot 56) \\
(0.60)\end{array}$ & $\begin{array}{l}2.77 \\
2.93\end{array}$ & $\begin{array}{l}(0 \cdot 55) \\
(0 \cdot 67)\end{array}$ & $\begin{array}{l}2 \cdot 74 \\
2 \cdot 88\end{array}$ & $\begin{array}{l}(0.55) \\
(0.60)\end{array}$ \\
\hline $\begin{array}{l}\text { Body mass index } \\
\quad<27 \\
>27\end{array}$ & $\begin{array}{ll}2.62 & (0.55) \\
2.72 & (0.54)\end{array}$ & $\begin{array}{l}2 \cdot 76 \\
2 \cdot 81\end{array}$ & $\begin{array}{l}(0.56) \\
(0.57)\end{array}$ & $\begin{array}{l}2 \cdot 76 \\
2 \cdot 83\end{array}$ & $\begin{array}{l}(0 \cdot 58) \\
(0.55)\end{array}$ & $\begin{array}{l}2 \cdot 73 \\
2 \cdot 79\end{array}$ & $\begin{array}{l}(0.56) \\
(0.57)\end{array}$ \\
\hline $\begin{array}{l}\text { Occupation: } \\
\text { Non-manual } \\
\text { Manual }\end{array}$ & $\begin{array}{ll}2.60 & (0.53) \\
2.71 & (0.56)\end{array}$ & $\begin{array}{l}2 \cdot 77 \\
2 \cdot 80\end{array}$ & $\begin{array}{l}(0.58) \\
(0.55)\end{array}$ & $\begin{array}{l}2 \cdot 69 \\
2 \cdot 84\end{array}$ & $\begin{array}{l}(0.50) \\
(0.59)\end{array}$ & $\begin{array}{l}2 \cdot 72 \\
2 \cdot 79\end{array}$ & $\begin{array}{l}(0.54) \\
(0.55)\end{array}$ \\
\hline
\end{tabular}

Within each grouping (age, etc) fibrinogen concentration was lower in those reporting strenuous exercise $(\mathrm{p}<0.0001)$. Effects of age, smoking, alcohol intake, BMI, and occupation on fibrinogen (p $<0.0001$ ). 
Table 3 Mean values (95\% confidence intervals) adjusted for age, smoking, alcohol habit, BMI, and non-manual occupation according to exercise intensity

\begin{tabular}{|c|c|c|c|c|}
\hline & \multicolumn{4}{|l|}{ Exercise intensity } \\
\hline & Strenuous (775) & Mild (2809) & None (255) & $p\left(F_{\text {test }}\right)$ \\
\hline $\begin{array}{l}\text { Fibrinogen } \\
\text { Mean } \\
95 \% \text { CI }\end{array}$ & $\begin{array}{l}2.70 \\
2.66 \text { to } 2.75\end{array}$ & $\begin{array}{l}2 \cdot 77 \\
2 \cdot 74 \text { to } 2 \cdot 80\end{array}$ & $\begin{array}{l}2 \cdot 70 \\
2 \cdot 70 \text { to } 2 \cdot 82\end{array}$ & 0.01 \\
\hline $\begin{array}{l}\text { VII (\% stan } \\
\text { Mean } \\
95 \% \mathrm{CI}\end{array}$ & $\begin{array}{l}86 \cdot 5 \\
84 \cdot 6 \text { to } 88 \cdot 4\end{array}$ & $\begin{array}{l}86 \cdot 0 \\
84 \cdot 8 \text { to } 87 \cdot 3\end{array}$ & $\begin{array}{l}88 \cdot 1 \\
85 \cdot 2 \text { to } 91 \cdot 1\end{array}$ & 0.35 \\
\hline $\begin{array}{c}\text { Systolic blo } \\
\text { Mean } \\
95 \% \text { CI }\end{array}$ & $\begin{array}{l}\operatorname{are}(\mathrm{mm} \mathrm{Hg}): \\
135 \cdot 8 \\
134.4 \text { to } 137 \cdot 3\end{array}$ & $\begin{array}{l}136.0 \\
135.0 \text { to } 137.0\end{array}$ & $\begin{array}{l}134.1 \\
131.9 \text { to } 136.4\end{array}$ & $0 \cdot 24$ \\
\hline $\begin{array}{c}\text { Cholesterol } \\
\text { Mean } \\
95 \% \mathrm{CI}\end{array}$ & $\begin{array}{l}5.74 \\
5.65 \text { to } 5.83\end{array}$ & $\begin{array}{l}5.85 \\
5.79 \text { to } 5.91\end{array}$ & $\begin{array}{l}5.87 \\
5.74 \text { to } 6.01\end{array}$ & 0.03 \\
\hline
\end{tabular}

BMI, body mass index.

be smokers, drank more alcohol, were less obese, and were more likely to be in nonmanual occupations.

Table 2 shows mean fibrinogen concentrations according to type of exercise. Within each of the groupings for the personal characteristics, and without exception, the mean fibrinogen concentration in those reporting strenuous exercise was significantly lower than in those reporting mild or no exercise. Mean values in these last two groups were virtually identical. (Similar tables for systolic blood pressure, cholesterol, and VII $_{c}$ are available on request and show less consistent or no relations with exercise: see also table 3 .)

Table 3 shows mean values (taking account of all the independent variables). The effect of strenuous exercise on fibrinogen remained significant and was probably similar for cholesterol.

Table 4 shows fibrinogen concentration and VII $_{c}$ according to the number of occasions on which strenuous exercise was reported each month. The trend towards lower values with increasing frequency was statistically significant for VII $_{c}$ but not for fibrinogen (and there were no suggestive trends for cholesterol or blood pressure).

\section{Discussion}

As far as we are aware no large scale study has previously reported in detail on exercise and fibrinogen, in particular. Those that have commented in summary form have all found a trend or a definite effect similar to our results. The clearest result comes from 931 civil servants in the Whitehall study ${ }^{17}$ which used a method for

Table 4 Mean values (95\% confidence intervals) adjusted for age, smoking, alcohol habit, BMI, and occupation according to monthly frequency of strenuous exercise

\begin{tabular}{|c|c|c|c|c|c|}
\hline & \multicolumn{4}{|l|}{ Frequency/month } & \multirow[b]{2}{*}{$p\left(F_{\text {test }}\right)$} \\
\hline & $1-3(n=160)$ & $4-7(n=189)$ & $8-11(n=121)$ & $12+(n=293)$ & \\
\hline $\begin{array}{c}\text { Fibrinogen } \\
\text { Mean } \\
95 \% \mathrm{CI}\end{array}$ & $\begin{array}{l}\text { 1): } \\
2 \cdot 72 \\
2.63 \text { to } 2 \cdot 83\end{array}$ & $\begin{array}{l}2.63 \\
2.54 \text { to } 2 \cdot 74\end{array}$ & $\begin{array}{l}2.68 \\
2.57 \text { to } 2.79\end{array}$ & $\begin{array}{l}2 \cdot 69 \\
2 \cdot 60 \text { to } 2 \cdot 77\end{array}$ & 0.63 \\
\hline $\begin{array}{l}\text { VII (\% sta } \\
\text { Mean } \\
95 \% \mathrm{CI}\end{array}$ & $\begin{array}{l}\text { rd): } \\
87 \cdot 4 \\
82.8 \text { to } 92 \cdot 3\end{array}$ & $\begin{array}{l}88.6 \\
83.9 \text { to } 93.6\end{array}$ & $\begin{array}{l}82.5 \\
77.8 \text { to } 87.5\end{array}$ & $\begin{array}{l}82 \cdot 3 \\
78 \cdot 5 \text { to } 86 \cdot 2\end{array}$ & 0.003 \\
\hline
\end{tabular}

eliciting vigorous exercise similar to that of Morris et al. ${ }^{12}$ The Gothenburg study of 639 men $^{18}$ used a subjective four point scale and found an inverse relation between amount of physical activity and fibrinogen, though it was not statistically significant. In a Scottish study of 8824 men and women ${ }^{19}$ those inactive in leisure and those who had reduced their level of activity had higher fibrinogen concentrations that those who were and had stayed activedifferences that remained after standardising for smoking but not when social class was also taken into account. In a Danish study of 439 men, ${ }^{20}$ physical activity was significantly associated with a reduction in fibrinogen when behavioural and social variables were considered separately in multivariate analyses. When the analysis was repeated with simultaneous inclusion of these and several other variables the association was not significant, though measured fitness was associated with a reduction in fibrinogen concentration when all the variables were included. In a Russian study ${ }^{21}$ regular physical training in patients with ischaemic heart disease led to a fall in fibrinogen concentrations by comparison with an untrained group.

It is unlikely that the significantly lower fibrinogen concentrations in those reporting strenuous exercise in our study are the result of a selection effect due to health. In particular, those with a definite or possible past history of vascular disease were excluded either at the note-search stage or at screening.

Some misclassification of exercise grouping is likely to have occurred, probably in the direction of over-reporting of strenuous exercise by men who did not in fact exercise to this extent. If so, the true difference in fibrinogen between those taking strenuous exercise, on one hand, and those taking mild or no exercise, on the other, will be larger than our results suggest. We did not enquire about physical activity at work but few occupations now require heavy work and most strenuous physical activity currently takes place during leisure.

The differences in fibrinogen concentration in table 2 between those taking and not taking strenuous exercise are about $0 \cdot 10 \mathrm{~g} / \mathrm{l}$. The relation between fibrinogen concentration and the incidence of ischaemic heart disease is strong. Based on the results of the Northwick Park Heart Study ${ }^{2}$ (in which the strength of the association between fibrinogen and ischaemic heart disease is not atypical of the other prospective studies of fibrinogen), a difference of $0 \cdot 10 \mathrm{~g} / \mathrm{l}$ would alter the risk of a major event of ischaemic heart disease by about $15 \%$. The smaller difference of about $0.06 \mathrm{~g} / \mathrm{l}$ in table 3 suggests a change in risk due to strenuous exercise of about $8 \%$, though (as already indicated) both these estimates are probably conservative because of some misclassification of exercise intensity. If it can be assumed that those reporting no exercise took less than those reporting mild exercise, it is noteworthy that in identifying strenuous but not mild exercise as being associated with lower fibrinogen concentrations, our results accord with those of 
Morris et al, ${ }^{12}$ who found that it was only vigorous exercise that conferred protection against ischaemic heart disease.

The relations of frequency of strenuous exercise with the two clotting factors (table 4) call for further study, to establish or exclude an effect on $\mathrm{VII}_{c}$, in particular, because it is possible $^{22}$ that this does respond to very strenuous exercise. There may well have been differential recording inaccuracies of frequency, those claiming to have engaged in strenuous exercise only 1-3 times a month perhaps tending to include a higher proportion who in fact only took mild exercise.

While physical activity probably raises the concentration of high density lipoprotein cholesterol, it has not been consistently associated with a significant reduction in total cholesterol or systolic blood pressure in other population-based samples of adult men. ${ }^{2324}$ Our findings are consistent with this conclusion for blood pressure but suggest an effect of strenuous activity on cholesterol.

The several characteristics that probably influence the risk of ischaemic heart disease through an effect on fibrinogen concentration include $^{25}$ advancing age, obesity, diabetes, smoking, use of oral contraceptives and the occurrence of the menopause, low-grade occupation and job "stress", retarded growth during infancy, ${ }^{26}$ and (protective) moderate alcohol consumption. Many of these characteristics have similar effects on $\mathrm{VII}_{c}$. We conclude that the protective effect of strenuous exercise can probably be added to this list, further emphasising the central role of coagulability as a mediator of ischaemic heart disease risk.

With the recognition of plasma fibrinogen, in particular, as a strong and independent index of the risk of ischaemic heart disease and the growing availability of fibrinogen measurement, there is increasing interest in aspects of lifestyle that could reduce high concentrations. Dietary changes have little if any effect. ${ }^{27-29}$ Stopping smoking is the most effective measure. As table 2 suggests, strenuous exercise may confer an advantage in both smokers and non-smokers. If verified and more precisely quantified in further studies, the apparently beneficial effect of strenuous exercise on fibrinogen could provide both doctors and patients with a valuable and practical incentive towards prevention, particularly where the risk of ischaemic heart disease is substantially due to raised fibrinogen concentrations.

We thank the staff and study participants in the Framework practices for their help and continuing cooperation.

1 Meade TW, North WRS, Chakrabarti R, Stirling Y, Haines AP, Thompson SG. Haemostatic function and cardiovascular death: early results of a prospective study. Lancet 1980;i:1050-4.

2 Meade TW, Mellows S, Brozovic M, et al. Haemostatic function and IHD: principal results of the Northwick Park Heart Study. Lancet 1986;ii:533-7.

3 Wilhelmsen L, Korsan-Bengtsen K, Welin L, et al. Fibrin ogen as a risk factor for stroke and myocardial infarction N Engl J Med 1978;311:501-5.

4 Lowe GDO, Blood rheology in arterial disease: Clin Sci 1986;71:137-46.

5 Meade TW, Vickers MV, Thompson SG, Stirling Y, Haines AP, Miller GJ. Epidemiological characteristics of platelet aggregability. Br Med J 1985;290:428-32.

6 Gurewich V, Lipinski B, Hyde E. The effect of the fibrinogen concentration and the leukocyte count on intravascular fibrin deposition from soluble fibrin monomer cular fibrin deposition from soluble fibrin

7 Chooi CC, Gallus AS. Acute phase reaction, fibrinogen level and thrombus size. Thromb Res 1989;53:493-501.

8 Naski MC, Shafer JA. A kinetic model for the $\alpha$-thrombincatalyzed conversion of plasma levels of fibrinogen to fibrin in the presence of antithrombin III. $J$ Biol Chem 1991;19:352-6.

9 Meade TW, Imeson JD, Stirling Y. Effects of changes in smoking and other characteristics on clotting factors and the risk of IHD. Lancet 1987;ii:986-8.

10 Wilkes HC, Kelleher C, Meade TW. Smoking and plasma fibrinogen (letter). Lancet 1988;i:307-8.

11 Morris JN, Heady JA, Raffle PAB, Roberts CG, Parks JW. Coronary heart disease and $\mathrm{p}$

12 Morris JN, Clayton DG, Everitt MG, Semmence AM Burgess EH. Exercise in leisure time: coronary attack and death rates. Br Heart $J$ 1990;63:325-34.

13 Morris JN, Crawford MD. Coronary heart disease and physical activity of work. Evidence of a national necropsy survey Br Med J 1958;ii:1485-96.

14 Meade TW, Wilkes HC, Stirling Y, Brennan PJ, Kelleher C Browne $W$. Randomized controlled trial of low dose warfarin in the primary prevention of IHD in men at hig risk: design and pilot study. Eur Heart J 1988;9:836-43.

15 Meade TW. Low-dose warfarin and low-dose aspirin in the primary prevention of ischemic heart disease. $\mathrm{Am}$ Cardiol 1990;65:7c-11c.

16 Washburn RA, Adams LL, Haile GT. Physical activity assessment for epidemiologic research: the utility of two simplified approaches. Prev Med 1987;16:636-46.

17 Davey Smith G, Marmot MG, Etherington M, O'Brien JR. A work stress-fibrinogen pathway as a potential mechanism for employment grade differences in coronary heart on Preventive Cardiology, 1989, Washington DC.

18 Rosengren A, Wilhelmsen L, Welin L, Tsipogianni A, Teger-Nilsson AC, Wedel H. Social influences and cardiovascular risk facts as determinants of plasma fibrinogen diovascular risk facts as determinants of plasma fibrinogen concentration in a general population

19 Lee AJ, Smith WCS, Lowe GDO, Tunstall-Pedoe H. Plasma fibrinogen and coronary risk factors: The Scottis Heart Health Study. J Clin Epidemiol 1990;9:913-9.

20 Moller L, Kristensen TS. Plasma fibrinogen and ischemic heart disease risk factors. Arteriosclerosis Thrombosis 1991;11:344-50.

21 Dudaev VA, Dyukov IV, Borodkin VV, et al. Change of the level of fibrinogen and its high molecular derivatives as a result of physical training in CHD patients. Terapevticheskii Archiv 1986;58:62-6.

22 Gris JC, Schved JF, Feugeas O, Aguilar-Martinez $P$ Arnaud A, Sanchez N, Sarlat C. Impact of smoking, physical training and weight reduction on FVII, PAI-1 physical training and weight reduction on FVII, PAI-1 Haemost 1990;64:516-20.

23 Folsom AR, Caspersen CJ, Taylor HL, Jacobs DR, Luepker RV, Gomez-Marin O. Leisure time physical activity and its relationship to coronary risk factors in a populationbased sample: the Minnesota Heart Survey. Am J Cardiol 1985;55:21-6.

24 Shaper AG, Wannamethe G. Physical activity and ischaemic heart disease in middle-aged British men. Br Heart 1991;66:384-94.

25 Meade TW. The epidemiology of haemostatic and othe variables in coronary artery disease. In: Verstraete $M$ Vermylen J, Lijnen R, Arnout J. Thrombosis and Haemostasis 1987. Leuven: Leuven University Press, 1987;37-60.

26 Barker DJP, Meade TW, Fall CHD, et al. The relationship of fetal and infant growth to plasma fibrinogen in adult life. Br Med J 1992;304:148-52.

27 Simpson HCR, Mann JI, Chakrabarti R, et al. Effect of high fibre diet on haemostatic variables in diabetes. $\mathrm{Br}$ Med J 1982;284:1608.

28 Miller GJ, Martin JC, Webster J, et al. Association between dietary fat intake and plasma factor VII coagulant activity - a predictor of cardio-vascular mortality. Atherosclerosis, 1986;60:269-77.

29 Miller GJ, Cruickshank JK, Ellis LJ, et al. Fat consumption and factor VII coagulant activity in middle-aged men. An association between a dietary and thrombogenic coronary risk factor. Atherosclerosis 1989;78:19-24. 


\section{News from committees}

John Camm has sent a progress report from the committee on radiation hazards in cardiology. "The committee has met and decided to approach the problem under the following sub-headings: local and international standards, equipment and practice, guidelines for good practice, training/audit/ supervision, voluntary registrations scheme, angioplasty, catheter ablation, paediatric interventions. The sub-committee will meet again in May or June and a report is expected shortly thereafter. We will be pleased to receive any comments or information."

\section{News of meetings}

David Wood has written about a workshop on preventive cardiology. "A one day meeting on preventive cardiology is being organised by the British Cardiac Society's Committee on Epidemiology and Prevention, with the objective of drawing up clinical guidelines on the role of cardiologists at region and district level in strategies for prevention. The meeting will take the form of a workshop with invited cardiologists from every region in the country, and places will be limited to 40 . Discussion documents on the potential roles of a cardiologist in relation to primary prevention, on the investigation and management of risk factors in those who have already developed coronary disease, and on the rehabilitation of patients (both medical and surgical) will be circulated in advance and presented at the meeting. Small working groups will then form to agree clinical guidelines on prevention, separately for district and regional cardiologists. These will constitute the basis for the final report with recommendations that we plan to submit for publication in the British Heart Journal. The meeting will take place at Fitzroy Square on Wednesday 14 October, 1992."

Readers are urged not to delay in booking places (again restricted to 40) for the teach-in at Fitzroy Square on 10 November. It is being organised by Michael Davies who has chosen the title "Emerging Concepts in the Basic Processes of Atherogenesis". Despite being a didactic session, it will contain hot news, it will be fascinating, and it will be clinically relevant. The details of the programme are still being worked out, but David Leake of the University of Reading will speak on lipid structure and lipid oxidation, and Peter Weissberg on smooth muscle proliferation. As before, the session will start at 10 am and finish by $4 \mathrm{pm}$ for the sake of those who have to travel long distances. Lunch will be provided.

We have received the excellent news from Philip Poole-Wilson that the Congress of the European Society of Cardiology will be held in Britain in 1996. The venue will be Birmingham, the dates 25 to 29 August. This will be a great opportunity for British cardiology, but it will demand considerable thought and careful planning if we are to make the most of it. We have great confidence that it will be a great success. Now that we have at least one centre that can handle the large numbers and all the accoutrements of a major international conference we hope it will be the first of many.

\section{News of colleagues}

We have received news of the following new consultant appointments: John Creamer as cardiologist to Stoke on Trent, Jean McEwan as senior lecturer at University College Hospital, Jonathan Fox as physician with an interest in cardiology at Southport Hospital, David Hackett as physician with an interest in cardiology at St Albans and Hemel Hempstead, and Phillip Thomas as physician with an interest in cardiology at Singleton Hospital, Swansea. Finally, we are very pleased to record that Dennis Krikler, immediate past editor of the British Heart Journal, and Peter Sleight, immediate past editor of Cardiovascular Research, have been awarded British Cardiac Society medals that were made specially for them. The presentation was made to Dennis Krikler at the Society's annual meeting in Harrogate.

DOUGLAS CHAMBERLAIN President, British Cardiac Society DUNCAN DYMOND Secretary, British Cardiac Society, 9 Fitzroy Square,

\section{NOTICE}

The 1993 Annual Meeting of the British Cardiac Society will take place at the Wembley Conference Centre from 18 to 21 May.

\section{Correction}

Strenuous exercise, plasma fibrinogen, and factor VII activity. $J$ B Connelly, $J$ A Cooper, $T W$ Meade (May issue, volume 67: pages 351-4). An incorrect result appeared in table 3 of this paper. A correct version of table 3 appears below.

Table 3 Mean values (95\% confidence intervals) adjusted for age, smoking, alcohol habit, BMI, and non-manual occupation according to exercise intensity

\begin{tabular}{|c|c|c|c|c|}
\hline & \multicolumn{4}{|l|}{ Exercise intensity } \\
\hline & Strenuous (775) & Mild (2809) & None (255) & $p(F$ test $)$ \\
\hline $\begin{array}{l}\text { Fibrinogen }(\mathrm{g} / \mathrm{l}) \text { : } \\
\text { Mean } \\
95 \% \mathrm{CI}\end{array}$ & $\begin{array}{l}2.70 \\
2.66 \text { to } 2.75\end{array}$ & $\begin{array}{l}2 \cdot 77 \\
2 \cdot 74 \text { to } 2 \cdot 80\end{array}$ & $\begin{array}{l}2 \cdot 76 \\
2 \cdot 70 \text { to } 2 \cdot 82\end{array}$ & 0.01 \\
\hline $\begin{array}{l}\text { VII (\% standard): } \\
\text { Mean } \\
95 \% \mathrm{CI}\end{array}$ & $\begin{array}{l}86 \cdot 5 \\
84 \cdot 6 \text { to } 88 \cdot 4\end{array}$ & $\begin{array}{l}86 \cdot 0 \\
84.8 \text { to } 87 \cdot 3\end{array}$ & $\begin{array}{l}88 \cdot 1 \\
85 \cdot 2 \text { to } 91 \cdot 1\end{array}$ & 0.35 \\
\hline $\begin{array}{l}\text { Systolic blood pressu } \\
\text { Mean } \\
95 \% \text { CI }\end{array}$ & $\begin{array}{l}\operatorname{are}(\mathrm{mm} \mathrm{Hg}): \\
135.8 \\
134.4 \text { to } 137 \cdot 3\end{array}$ & $\begin{array}{l}136 \cdot 0 \\
135.0 \text { to } 137.0\end{array}$ & $\begin{array}{l}134.1 \\
131.9 \text { to } 136.4\end{array}$ & 0.24 \\
\hline $\begin{array}{l}\text { Cholesterol (mmol/l) } \\
\text { Mean } \\
95 \% \text { CI }\end{array}$ & $\begin{array}{l}5 \cdot 74 \\
5 \cdot 65 \text { to } 5 \cdot 83\end{array}$ & $\begin{array}{l}5.85 \\
5.79 \text { to } 5.91\end{array}$ & $\begin{array}{l}5.87 \\
5.74 \text { to } 6.01\end{array}$ & 0.03 \\
\hline
\end{tabular}

BMI, body mass index. 